\title{
Geochemical processes controlling the groundwater quality in lower Palar river basin, southern India
}

\author{
M Senthilkumar ${ }^{1}$ and L Elango ${ }^{2 * *}$ \\ ${ }^{1}$ Central Ground Water Board, Chennai 600 090, India. \\ ${ }^{2}$ Department of Geology, Anna University, Chennai 600 025, India. \\ *Corresponding author.e-mail: elango34@hotmail.com_elango@annauniv.edu
}

\begin{abstract}
Hydrogeochemical study of groundwater was carried out in a part of the lower Palar river basin, southern India to determine the geochemical processes controlling the groundwater quality. Thirty-nine groundwater samples were collected from the study area and analysed for $\mathrm{pH}$, Eh, EC, Ca, $\mathrm{Mg}, \mathrm{Na}, \mathrm{K}, \mathrm{HCO}_{3}$, $\mathrm{CO}_{3}, \mathrm{Cl}$ and $\mathrm{SO}_{4}$. The analysed parameters of the groundwater in the study area were found to be well within the safe range in general with respect to the Bureau of Indian Standards for drinking water except for few locations. The results of these analyses were used to identify the geochemical processes that are taking place in this region. Cation exchange and silicate weathering are the important processes controlling the major ion distribution of the study area. Mass balance reaction model NETPATH was used to assess the ion exchange processes. High concentration of $\mathrm{Ca}$ in groundwater of the study area is due to the release of $\mathrm{Ca}$ by aquifer material and adsorption of $\mathrm{Na}$ due to ion exchange processes. Groundwater of the study area is suitable for drinking and irrigation purposes except for few locations.
\end{abstract}

\section{Introduction}

Groundwater is the major source of fresh water, which is widely used for domestic, industrial and agricultural purposes in most parts of the world. It is a replenishable resource and has inherent advantages over the surface water as it is comparatively pure, less evaporation loss, wide distribution, etc. The chemistry of groundwater is mainly controlled by the geochemical reactions that take place along the direction of flow. It is necessary to identify these geochemical reactions in the aquifer in order to assess the distribution of major ion chemistry of the region (Fisher and Mullican 1997; Rosen and Jones 1998; Mohan et al. 2000; Satyanarayanan et al. 2007; Reddy et al. 2010; Reddy and Kumar 2010; Tirumalesh et al. 2010; Raju et al. 2011). Studying the seasonal and temporal variation of various ions in groundwater helps to identify the major processes controlling the composition of groundwater in a particular area (Laluraj and Gopinath 2006; Raju 2006; Rao 2006; Andrade and Stigter 2011; Rouxel et al. 2011). Apart from this, human activities such as contamination due to industrial effluents, landfills, application of fertilizers, etc., may also play a role in influencing the groundwater composition (Mazari and MacKay 1993; Kumaresan and Riyazuddin 2006; Li et al. 2006; Al-Sabahi et al. 2009; Brindha et al. 2010; Aghazadeh and Mogaddam 2011; Bakis and Tuncan 2011; Vijay et al. 2011; Brindha and Elango 2012). Knowledge on groundwater quality of any area is essential for managing and sustaining the resource for various uses. With this motive, several researchers around the globe have given importance to groundwater quality (Gowd 2005; Özcan et al. 2007; Arumugam and Elangovan 2009; Raju et al. 2009; Belkhiri et al. 2010; Dar et al. 2011). This

Keywords. Hydrogeochemistry; ion exchange; silicate weathering; NETPATH; geochemical model. 
study was carried out in a part of the lower Palar river basin, southern India with the objectives of determining the hydrogeochemical nature of the groundwater in this region, to identify the geochemical processes responsible for the present status of groundwater quality and to assess the suitability of groundwater for drinking and irrigational purposes. This region is mainly dependent upon groundwater for irrigation, domestic and drinking needs and the groundwater quality of this area for the above-mentioned purposes have not been identified earlier.

\section{Study area}

A part of the lower Palar river basin, Tamil Nadu, India was considered for this study. It is located $75 \mathrm{~km}$ south of Chennai (formerly Madras) and covers an area of $392 \mathrm{~km}^{2}$ (figure 1). The eastern side of this area is bounded by the Bay of Bengal. This area enjoys sub-tropical monsoon climate with January and February as the dry periods, March to May as summer period, followed by the monsoon period. The maximum temperature in this area is about $42^{\circ} \mathrm{C}$ during the months of May and
June and the minimum temperature is about $21^{\circ} \mathrm{C}$ recorded during the months of December and January. The southwest monsoon (June-September), the northeast monsoon (October-December) and the transition period contribute $40 \%, 51 \%$ and $9 \%$ respectively, of the total annual rainfall $(1167 \mathrm{~mm} /$ year) in the study area. This area is more or less bisected into two halves by the Palar river which is a seasonal river and flows during the months of November, December and January. Numerous reservoirs are present in the depressed parts of the undulating topography of the study area.

\section{Hydrogeology}

The study area exhibits varied physiographic features and the elevation ranges from $40 \mathrm{~m}$ above msl in the west to sea level in the east. Geologically, the study area has two distinct formations (figure 2): crystalline rocks of Archean age and recent alluvium. These alluvial deposits occur along the present and paleo Palar river courses. Crystalline rocks comprising of charnockites and granitic gneisses form the basement and some exposures are found in the southern part of this area. The

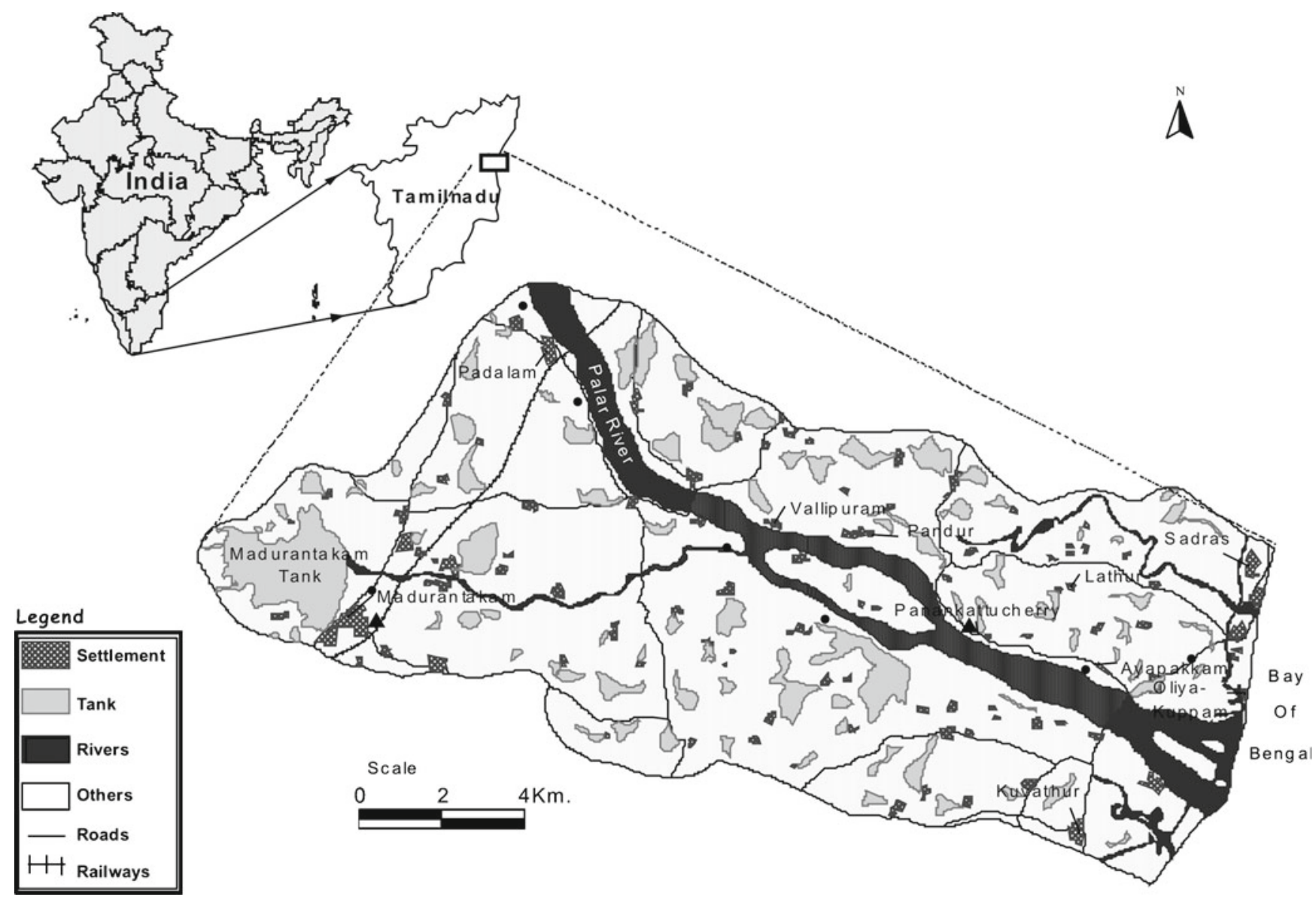

Figure 1. Location of the study area. 


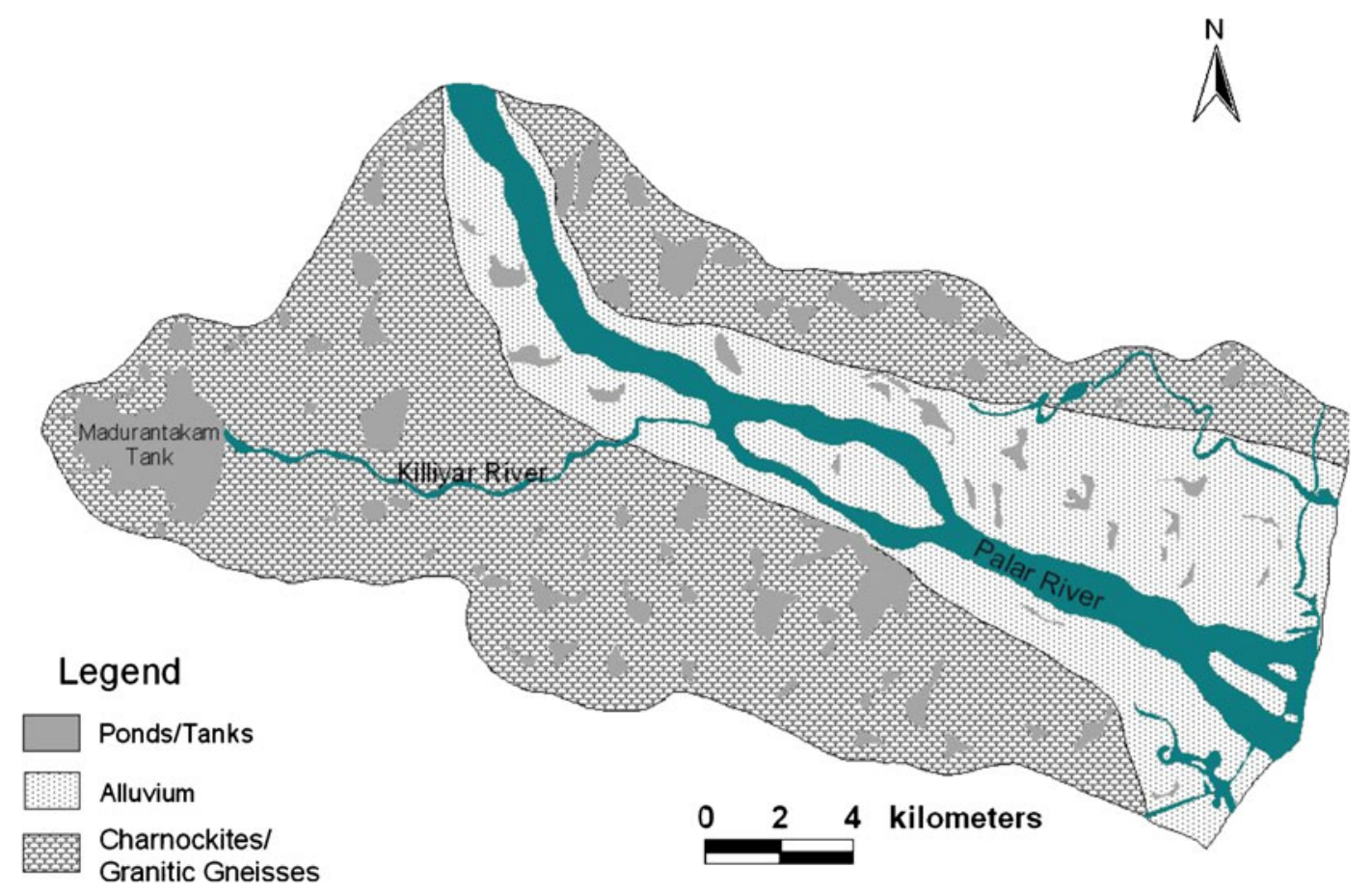

Figure 2. Geology of the study area.

alluvium and weathered crystalline charnockites function as an aquifer system. The alluvium consists of sand and interlaying clay lenses. Alluvium occasionally contains calcite and dolomite in the form of evaporates. The clays are characterised by montmorillonite, kaolinite and illite. Groundwater occurs in unconfined condition in both the alluvial and underlying weathered rocks. Alluvium occurring in the upper part is characterised by sand, gravel and sandy clay, with the thickness ranging from $1 \mathrm{~m}$ at the northern and southern boundaries to $30 \mathrm{~m}$ along the river. The hydraulic conductivity of this alluvium ranges from 20 to $68 \mathrm{~m} /$ day and the specific yield value ranges from 0.037 to 0.18 which are derived from pumping test carried out in the alluvial deposits (PWD 2000). The lower layer is characterised by weathered crystalline rocks. The thickness of the weathered layer varies from 0 to $7 \mathrm{~m}$. The hydraulic conductivity of this layer ranges from 0.5 to $12 \mathrm{~m} /$ day, and transmissivity varies from 10 to $80 \mathrm{~m}^{2} /$ day (PWD 2000).

\section{Methodology}

\subsection{Sampling and analysis}

Groundwater samples were collected from 39 representative wells spread throughout the study area (figure 3). About 585 samples were collected from the 39 sampling locations every month from April 2001 to June 2002 from both open and borewells.
The hydrogeochemical characteristics of water and its potability were obtained from physiochemical analysis of the groundwater samples. Groundwater samples were collected in $500 \mathrm{ml}$ polyethylene bottles. All the sampling bottles were soaked with 1:1 $\mathrm{HNO}_{3}$ and rinsed using double distilled water. At the time of sampling, sampling bottles were thoroughly rinsed two or three times using the groundwater to be sampled. In case of bore wells, groundwater samples were collected after pumping for sufficient time. Electrical conductivity (EC in $\mu \mathrm{S} / \mathrm{cm})$, hydrogen-ion activity $(\mathrm{pH})$ and redox potential (Eh in $\mathrm{mV}$ ) of groundwater samples were measured in the field with the use of digital portable meters. TDS (total dissolved solids) was calculated using the formula, $\operatorname{TDS}(\mathrm{mg} / \mathrm{l})=\mathrm{EC}(\mu \mathrm{S} /$ $\mathrm{cm}) \times 0.64$.

The collected groundwater samples were filtered using $0.45 \mathrm{~mm}$ Millipore filter paper and acidified with nitric acid for analysis. The samples were analysed for concentrations of $\mathrm{Ca}, \mathrm{Mg}, \mathrm{Na}$, and $\mathrm{K}, \mathrm{CO}_{3}, \mathrm{HCO}_{3}, \mathrm{Cl}$ and $\mathrm{SO}_{4}$. The analytical procedures used were according to APHA (1995) and the methods adopted were titrimetric method for $\mathrm{Ca}$ and $\mathrm{Mg}$, flame photometric method for $\mathrm{Na}$ and $\mathrm{K}$, titration using $0.01 \mathrm{~N} \mathrm{H}_{2} \mathrm{SO}_{4}$ for $\mathrm{HCO}_{3}$ and $\mathrm{CO}_{3}$, titration using $0.05 \mathrm{~N} \mathrm{AgNO}_{3}$ for $\mathrm{Cl}$ and spectrophotometric method for $\mathrm{SO}_{4}$. During the analytical procedures, blanks and standards were run to check the reliability of the methods adopted. After completion of the analysis of major ions, the ion balance error was calculated and it was within $\pm 10 \%$. The analysis was carried out immediately 


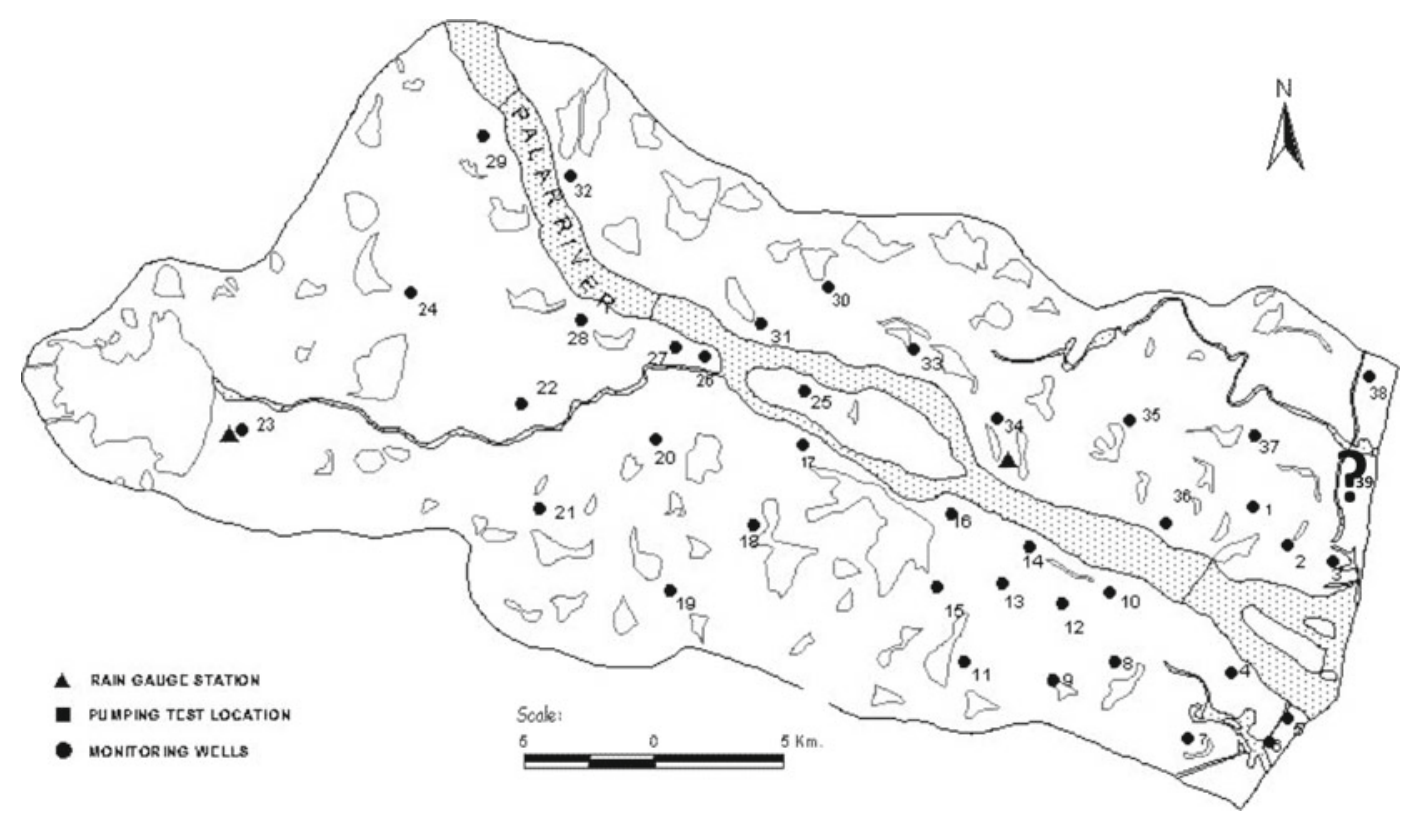

Figure 3. Location of monitoring wells in the study area.

after the collection of water samples at the Hydrogeochemistry lab of the Department of Geology, Anna University.

\subsection{Model description}

NETPATH (Plummer et al. 1991) is an interactive Fortran 77 program used to interpret net mass balance reactions. NETPATH enables calculation of different species of solutions, molal concentration and the activities of each one of the ions and the chemical reactions and the mass transfers along the flow path. The code NETPATH consists of programs such as DB, WATQF and NETPATH. DB is an interactive program that allows for storage of chemical analysis data. The saturation indices (SI) of the phases based on the input of analytical data can also be calculated.

The NETPATH code is designed to define and quantify chemical reactions that are consistent with the initial chemical data along the flow paths. For a set of minerals or gas phases hypothesized to be the reactive phases in the system, NETPATH calculates the mass transfers in every possible combination of the selected phases that accounts for the observed changes in the selected chemical compositions observed along the flow path.

\section{Results and discussion}

\subsection{General hydrochemistry}

The $\mathrm{pH}$ of groundwater samples vary from 6.9 to 8.9. The central part of the study area has relatively high $\mathrm{pH}$. Almost all the samples are generally neutral except for the sample collected from well no. 30, which is slightly alkaline. EC of groundwater collected from the study area ranges from 290 to $2100 \mu \mathrm{S} / \mathrm{cm}$. The spatial variation of $\mathrm{EC}$ in the month of January 2002 is shown in figure 4. Groundwater of well no. 30 has high EC. Eh value ranges from -33 to $+303 \mathrm{mV}$. Groundwater in well no. 35 has the lowest value of $-33 \mathrm{mV}$, indicating the lack of oxygen.

The order of dominance of the cations of the study area is $\mathrm{Na}>\mathrm{Ca}>\mathrm{Mg}>\mathrm{K}$ and of the anions is $\mathrm{HCO}_{3}>\mathrm{Cl}>\mathrm{CO}_{3}>\mathrm{SO}_{4}$. Ca ranges from 21 to $251 \mathrm{mg} / \mathrm{l}$ and $\mathrm{Mg}$ ranges from 6 to 94 $\mathrm{mg} / \mathrm{l}$. Na concentration of the study area varies from 10 to $138 \mathrm{mg} / \mathrm{l}$ and $\mathrm{K}$ values range from 5 to $183 \mathrm{mg} / \mathrm{l} . \mathrm{HCO}_{3}$ is the dominant anion, which ranges from 23 to $591 \mathrm{mg} / \mathrm{l}$ and the $\mathrm{Cl}$ content is in the range of 25 to $1522 \mathrm{mg} / \mathrm{l}$. A few groundwater samples along the coastal side have high concentration of $\mathrm{Cl}$. $\mathrm{SO}_{4}$ concentration is very low and it ranges from $<1$ to $30.5 \mathrm{mg} / \mathrm{l}$.

Groundwater is used for drinking, domestic, irrigational and industrial purposes in this area. Hence, it is essential to determine its suitability in order to use it for drinking and irrigational purposes. The analytical results were compared with the WHO (1984) and the Indian Standards for drinking water (ISI 1983). The results of the hydrochemical analysis show that the groundwater of the study area is suitable for drinking and domestic purposes with few exceptions. Most of the parameters are well within the permissible limits. Total hardness $(\mathrm{TH})$ ranges from 91 to $919 \mathrm{mg} / \mathrm{l}$. Most of the $\mathrm{TH}$ values are half the values of TDS of the samples. The groundwater in well no. 30 has 


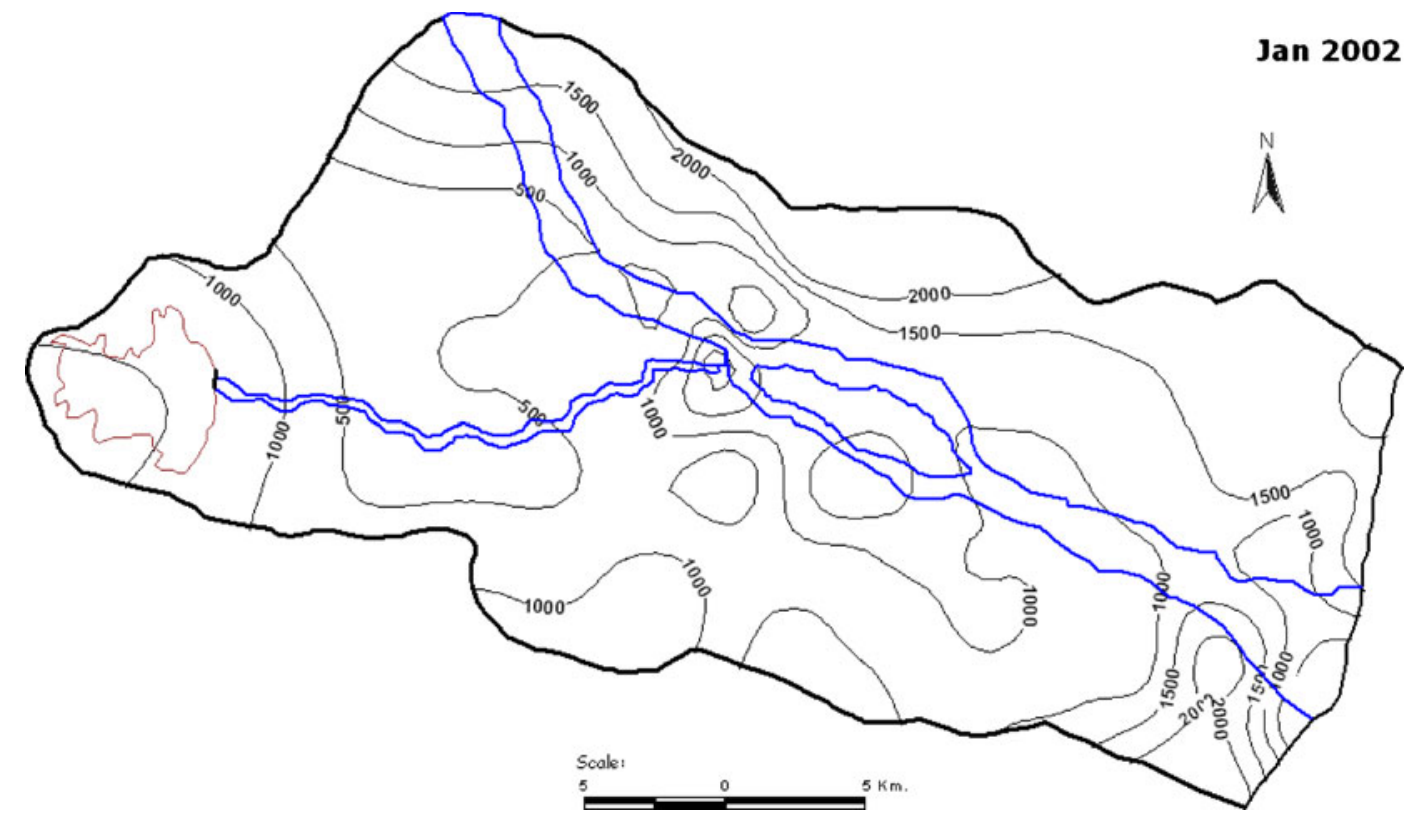

Figure 4. Spatial distribution of $\mathrm{EC}(\mu \mathrm{S} / \mathrm{cm})$ in groundwater of the study area during January 2002.

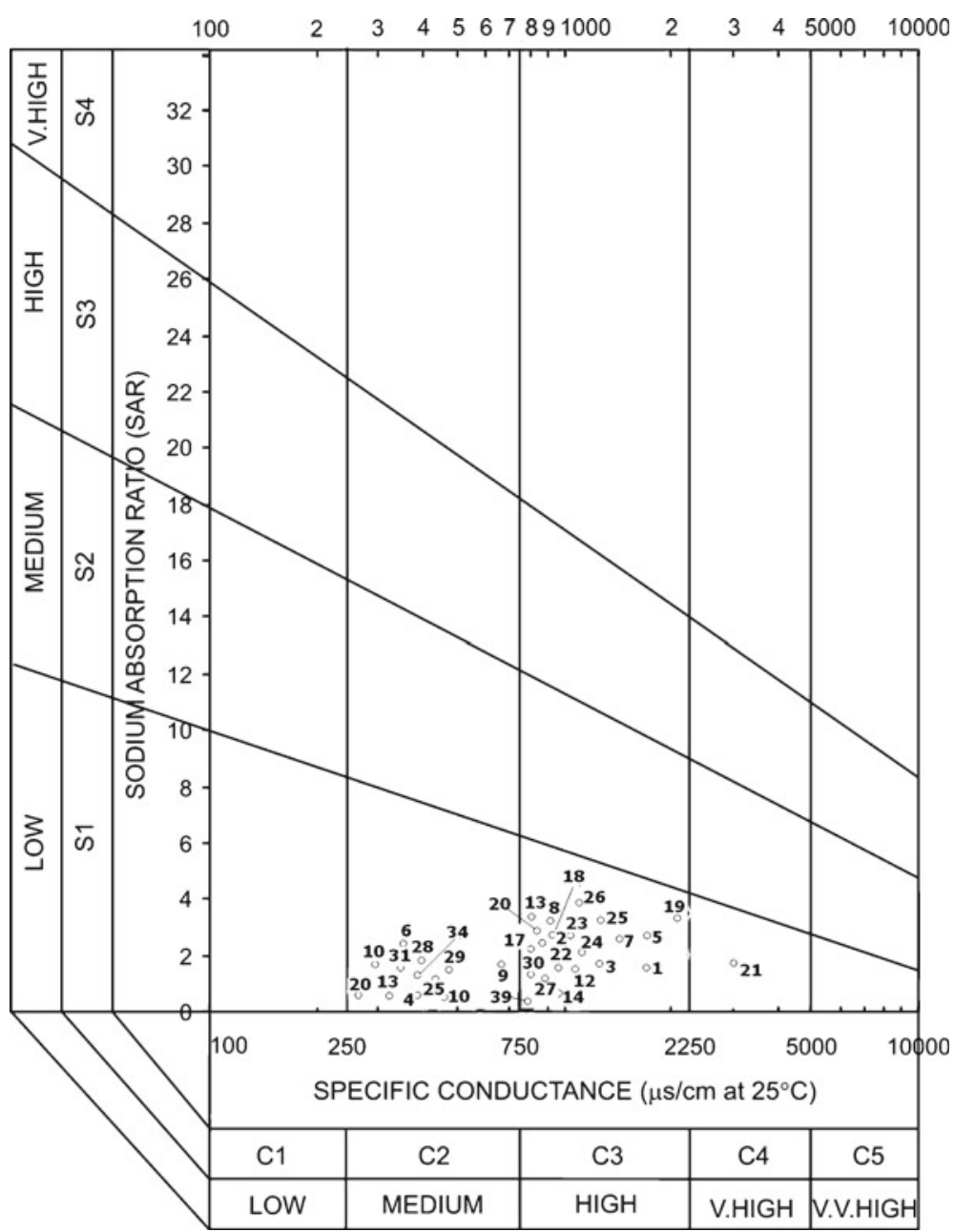

Figure 5. USSL diagram indicating the suitability of groundwater for irrigation. 
the maximum value of $\mathrm{TH}$ of $919 \mathrm{mg} / \mathrm{l}$. TH of the groundwater samples vary between hard to moderate with few samples located in well nos. 5, 30, 36 and 17 falling under the very hard category. Hardness has no known adverse effect on health, but it prevents formation of lather with soap. It also increases the boiling point of water. The TDS and $\mathrm{EC}$ values exceed permissible limit in some sites of the study area. The $\mathrm{Cl}$ concentration in the groundwater samples of the study area is well within the safe range except in few locations such as well nos. 30, 5 and 29 where it exceeds the permissible limit.

To examine the suitability of groundwater for irrigation purposes, the parameters such as SAR (Na Adsorption Ratio), Na percentage (Na\%) and residual sodium carbonate (RSC) were estimated. The U.S. Salinity laboratory classification (USSL) was applied to the groundwater samples of the study area which is based on SAR and EC. The USSL diagram (figure 5) shows that most of the groundwater samples of the study area have
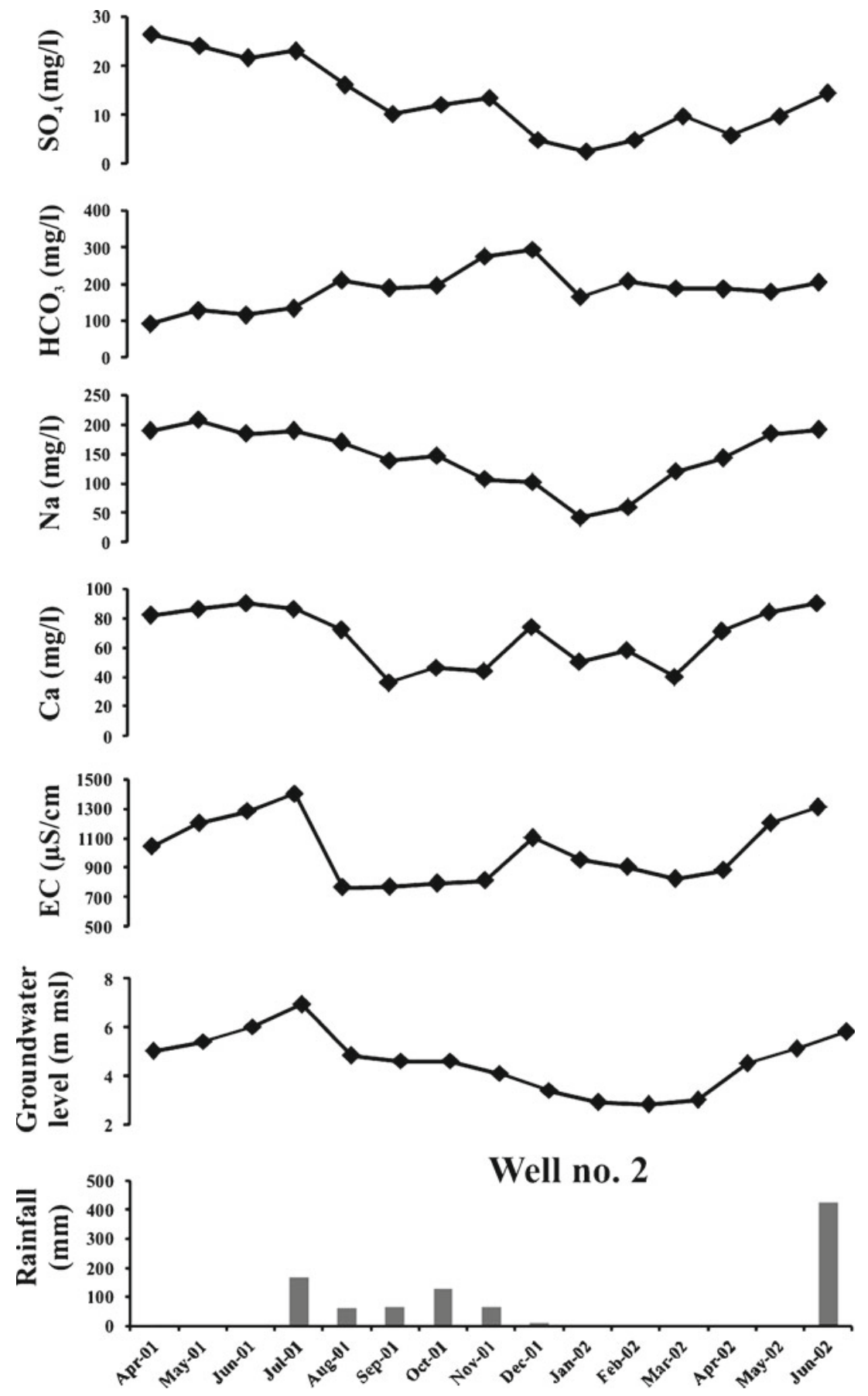

Figure 6. Monthly variation in rainfall $(\mathrm{mm})$, groundwater level $(\mathrm{m} \mathrm{msl})$ and concentration of various ions in groundwater. 

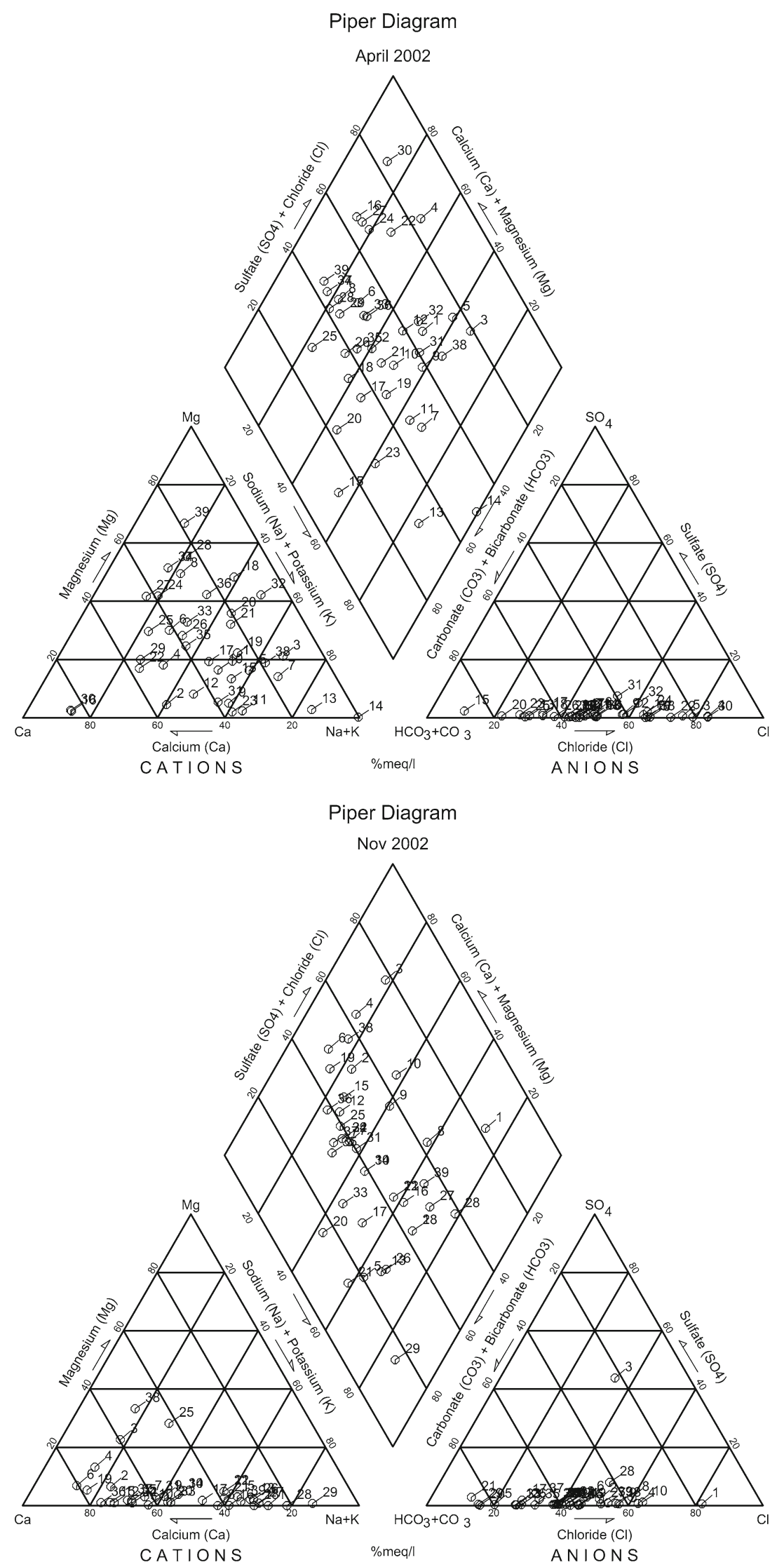

Figure 7. Piper trilinear diagram indicating the groundwater type. 
high salinity and low $\mathrm{Na}$ content (C3-S1) and few samples have medium salinity and low $\mathrm{Na}$ ion exchange (C2-S1). Groundwater of both the categories $\mathrm{C} 2-\mathrm{S} 1$ and $\mathrm{C} 3-\mathrm{S} 1$ can be used for irrigation on almost all soils, with a little danger of development of harmful level of exchangeable $\mathrm{Na}$ in the C3S1 category. Only one groundwater sample location (well no. 30) of the study area falls in the category of very high salinity and low Na content (C4-S1). The Na\% in the study area ranges from $9 \%$ to $67 \%$. As per the BIS standards, maximum of $60 \% \mathrm{Na}$ is recommended for irrigation purposes. Out of the 39 groundwater samples, eight groundwater samples have Na percentage higher than the prescribed limit for irrigation.

Most of the groundwater samples of the study area have RSC values ranging from safe to moderate class. A high value of RSC in groundwater leads to increase in the adsorption of $\mathrm{Na}$ on soil (Eaton 1950). Groundwaters of these classes are suitable for irrigation. Few groundwater samples of the study area have RSC values above $4.5 \mathrm{meq} / \mathrm{l}$.

Monthly variations (figure 6) of groundwater ionic concentration of this area indicate that rainfall is the major source for variations in groundwater chemistry. In many of the wells the concentration of ions is found to increase immediately after the rise in groundwater level. This is due to the flushing of salts deposited due to evaporation in the upper zones during the preceding dry season as reported by Elango (1992).

\subsection{Hydrochemical facies}

Piper trilinear plot prepared with the hydrochemical results of groundwater collected during April 2002 and November 2002 apparently illustrates distinct hydrochemical facies (figure 7 ). Four hydrochemical facies have been identified based on the major ion chemistry of the groundwater of this area, of which (i) $\mathrm{Ca}-\mathrm{Mg}-\mathrm{HCO}_{3}$, and (ii) $\mathrm{Na}-$ $\mathrm{K}-\mathrm{HCO}_{3}$ are the major facies. Few groundwater samples of the coastal area show $\mathrm{Na}-\mathrm{Cl}$ facies during the summer period (April). But these samples gradually get diluted to $\mathrm{Ca}-\mathrm{Mg}-\mathrm{HCO}_{3}$ or $\mathrm{Na}-\mathrm{K}-\mathrm{HCO}_{3}$ facies with the monsoon.

\subsection{Geochemical processes}

Identifying and understanding the hydrogeochemical processes are essential to evaluate the causes for changes in groundwater quality for planning groundwater protection. Gibbs (1970) plot (figure 8) was used to identify the mechanisms that control the groundwater chemistry of the study area. This plot shows that most of the data points plot in the
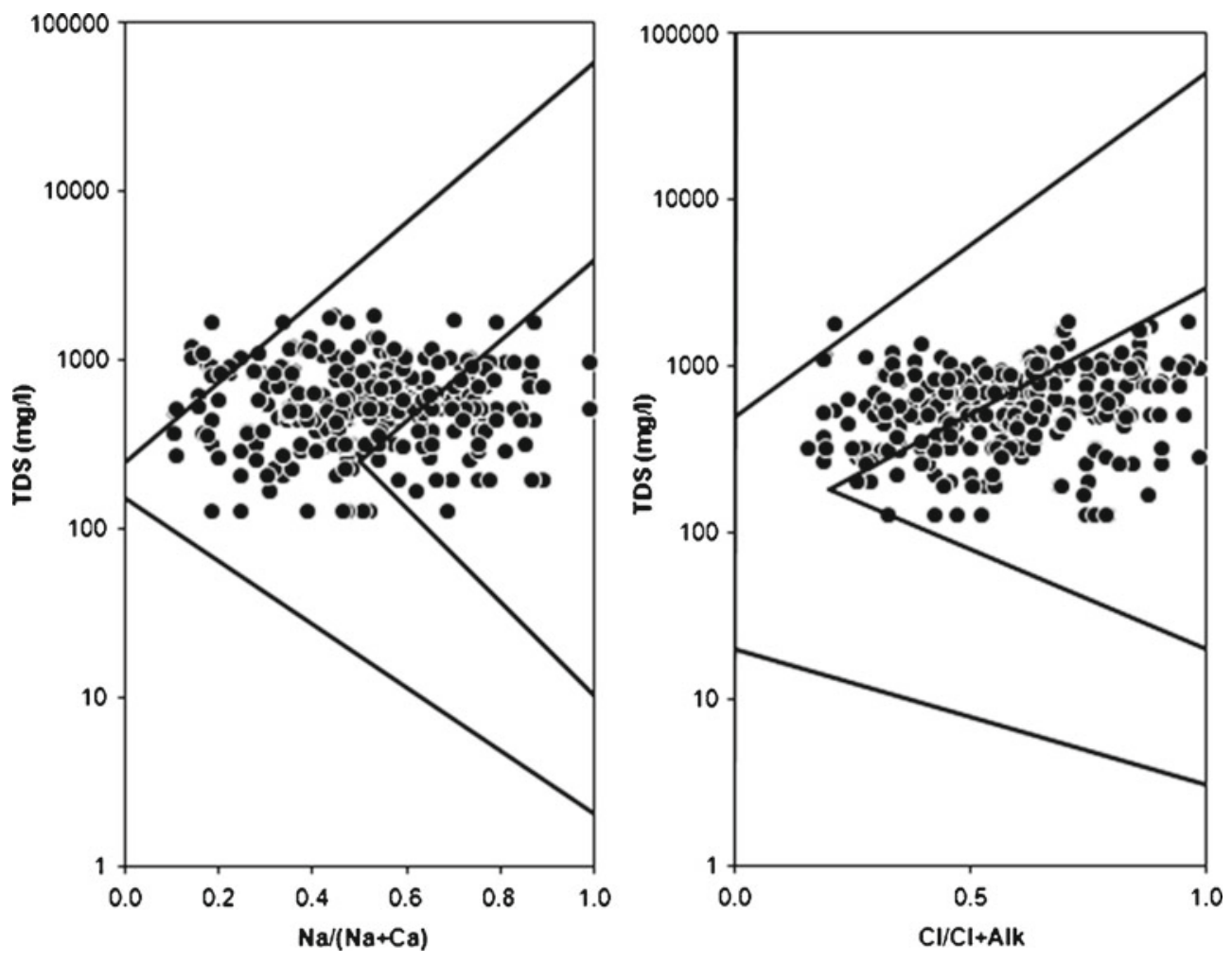

Figure 8. Gibbs plot showing geochemical processes in groundwater of the study area. 
rock dominance zone except a few in the evaporation zone which indicate that interaction between aquifer material and water is the major process controlling the groundwater chemistry of this area.

\subsubsection{Evaporation}

Plot of $\mathrm{Na}$ versus $\mathrm{Cl}$ and $\mathrm{Na} / \mathrm{Cl}$ ratio versus EC (figure 9a and b) shows that evaporation is not the major process in this area. Concentration by evaporation process assuming that no mineral species are precipitated, would leave the ratio of $\mathrm{Na} / \mathrm{Cl}$ unchanged. Another plot of the $\mathrm{Na} / \mathrm{Cl}$ versus EC would therefore produce a horizontal line (Jankowski and Acworth 1997; Rajmohan and Elango 2004). The $\mathrm{Na} / \mathrm{Cl}$ ratio vary widely in groundwater of this area (figure $9 \mathrm{a}) . \mathrm{Na} / \mathrm{Cl}$ ratio
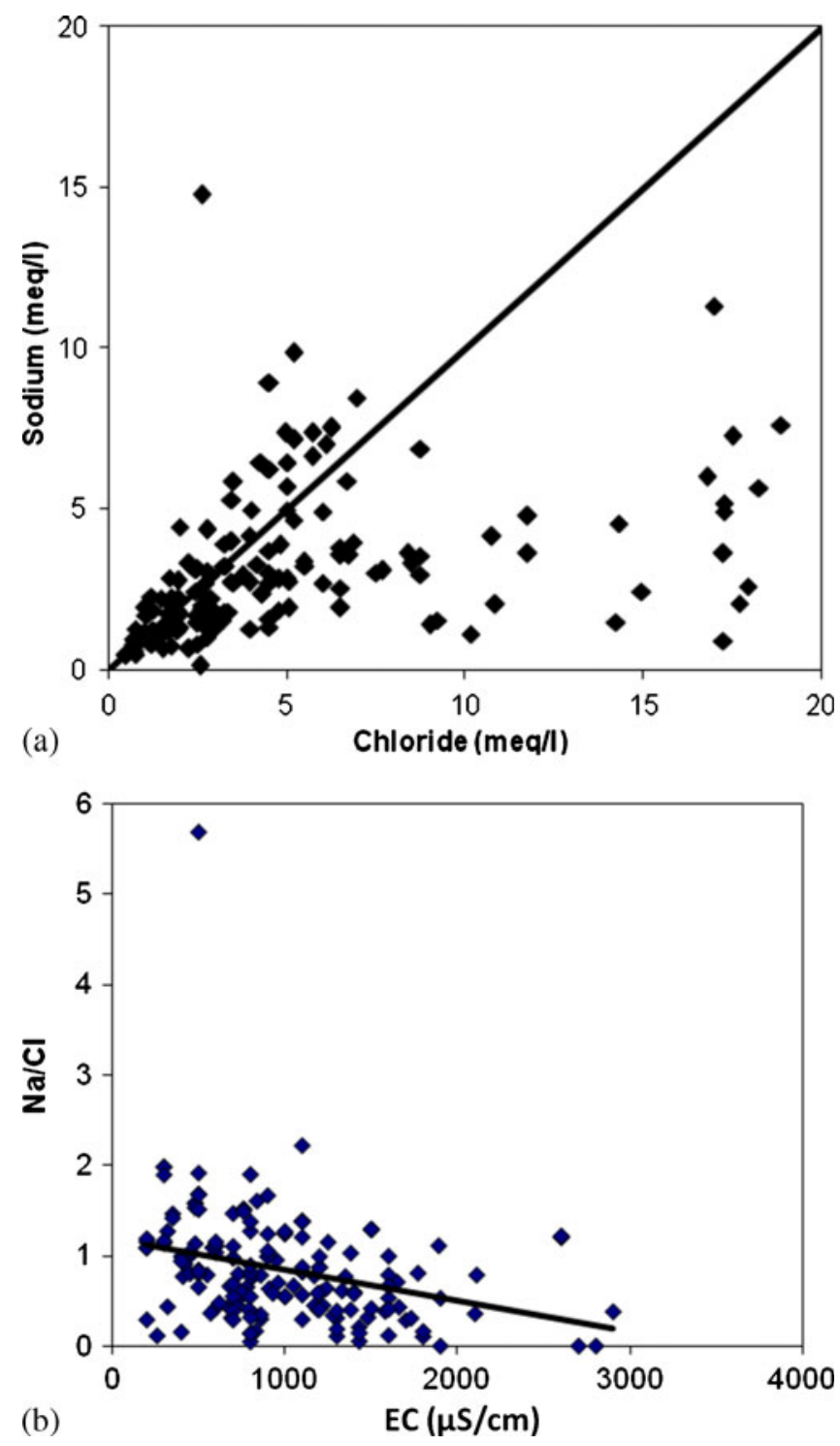

Figure 9. (a) Relation between $\mathrm{Na}$ (meq/l) and $\mathrm{Cl}$ (meq/l). (b) Relation between $\mathrm{Na} / \mathrm{Cl}$ versus $\mathrm{EC}(\mu \mathrm{S} / \mathrm{cm})$. versus EC (figure 9b) of the study area shows a slightly inclined relationship, which indicates that evaporation is not a dominant process in the study area. Slightly elevated $\mathrm{Na}$ in groundwater of this area indicates that silicate weathering is likely to be a major cause than evaporation. High $\mathrm{Na}$ content in groundwater in a watershed in southern India observed by Reddy et al. (2010) was due to weathering of silicate rocks such as granitic gneiss followed by evaporation process.

\subsubsection{Cation-exchange reaction}

Cation exchange reactions are the important geochemical reactions which control the distribution and occurrence of ions in groundwater. Cation exchange process can be identified using a relationship between the $\mathrm{Na}$ and $\mathrm{Cl}$ ions. Ion exchange and industrial and/or agricultural contamination are likely responsible for increase in sodium in a gneissic terrain (Guo and Wang 2004). High concentration of $\mathrm{Na}$ with respect to $\mathrm{Cl}$ or depletion of $\mathrm{Na}$ with respect to $\mathrm{Cl}$ is the evidence of cation exchange reactions (Salama 1993; Rajmohan and Elango 2004). In the normal ion exchange reaction, $\mathrm{Ca}$ is retained in the aquifer material and $\mathrm{Na}$ is released to water. The excess $\mathrm{Na}$ generated by ion exchange reaction is not balanced by $\mathrm{Cl}$ but by alkalinity or $\mathrm{SO}_{4}$. Similarly, in the reverse ion exchange, $\mathrm{Na}$ is retained by aquifer materials and $\mathrm{Ca}$ is released to water. In this case, excess $\mathrm{Cl}$ over $\mathrm{Na}$ is balanced by $\mathrm{Ca}$ and $\mathrm{Mg}$. Hence, excess $\mathrm{Na}$ over $\mathrm{Cl}$ or excess $\mathrm{Cl}$ over $\mathrm{Na}$ is a good indication for ion exchange reactions. This area is characterised by the depletion of $\mathrm{Na}$ values with respect to $\mathrm{Cl}$ (figure 9a), which is an evidence for ion exchange reaction. Further, cation exchange is also identified by the reduction in the levels of $\mathrm{Ca}$ with respect to $\mathrm{Na}$ (figure 10) as reported by Jankowski and

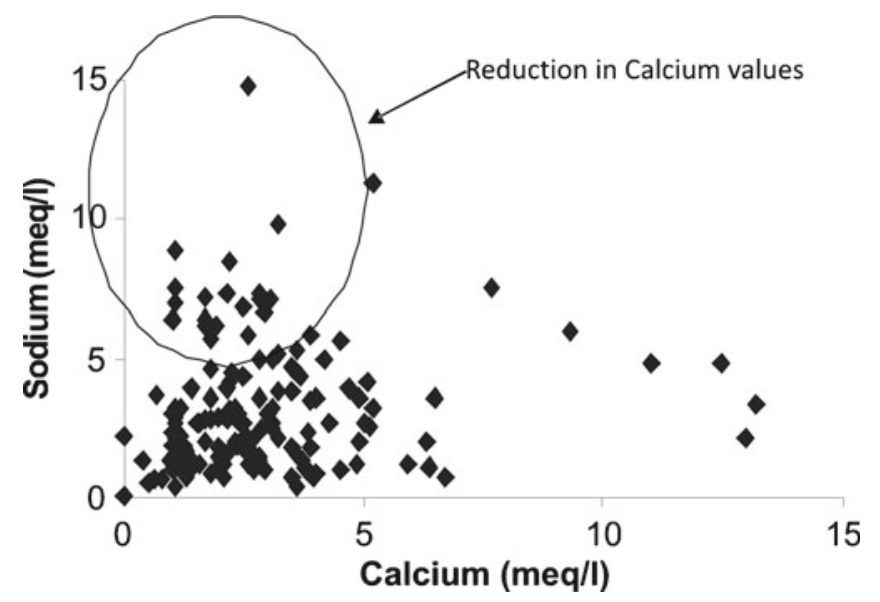

Figure 10. Relationship between $\mathrm{Ca}$ and $\mathrm{Na}$ showing cation exchange reaction. 
Acworth (1997). Thus, it is evident that cation exchange processes play an important role as one of the geochemical processes controlling the groundwater chemistry of this region. The evidence for ion exchange in the development of salinisation can lead to release of $\mathrm{Na}$ from clay minerals, replacing $\mathrm{Ca}$ that is present in groundwater of a charnockite region in southern India (Rao 2008).

\subsubsection{Silicate weathering process}

Evidences for silicate weathering can be explained by the relationships of $\mathrm{Ca}+\mathrm{Mg}$ versus $\mathrm{HCO}_{3}$ (figure 11a). Figure 8(a) shows that most of the data points fall above the 1:1 equiline (excess $\mathrm{Ca}+$ $\mathrm{Mg}$ ). This situation requires a part of the $\mathrm{CO}_{3}$ alkalinity to be balanced by alkalis. The $\mathrm{Ca}+\mathrm{Mg}$ versus total cations (figure 11b) plot shows that the data points lie below the 1:1 equiline. The plot of $\mathrm{Na}+\mathrm{K}$ versus total cations (figure 11c) also shows that the data points fall below the 1:1 equiline. This relatively high contribution of $\mathrm{Na}+\mathrm{K}$ to the total cations is an indication of silicate weathering (Mohan et al. 2000; Rajmohan and Elango 2004). A molal $\mathrm{Na} / \mathrm{Cl}$ (figure 9a) ratio greater than one is typically interpreted as reflecting $\mathrm{Na}$ released from silicate weathering reactions (Meybeck 1987). The $\mathrm{Na} / \mathrm{Cl}$ ratio in groundwater samples more than 1 indicating that $\mathrm{Na}$ was released from silicate weathering was also reported in metamorphic rocks of sedimentary and magmatic origin in Iran by Jalali (2010). Silicate dissolution is the probable source for $\mathrm{Na}$ in the study area because water that derives solutes primarily by silicate weathering would have $\mathrm{HCO}_{3}$ as the most abundant anion (Fisher and Mullican 1997). This is because of the reaction of feldspar minerals with carbonic acid in the presence of water, which releases $\mathrm{HCO}_{3}$ (Elango et al. 2003), which is illustrated by the following equation:

$$
\begin{aligned}
& 2 \mathrm{NaAlSi}_{3} \mathrm{O}_{8}+2 \mathrm{H}_{2} \mathrm{CO}_{3}+9 \mathrm{H}_{2} \mathrm{O} \\
& \quad \text { Albite } \\
& =\underset{2}{\mathrm{Al}_{2} \mathrm{Si}_{2} \mathrm{O}_{5}(\mathrm{OH})_{4}+2 \mathrm{Na}+4 \mathrm{H}_{4} \mathrm{SiO}_{4}+2 \mathrm{HCO}_{3}} \\
& \quad \text { Kaolinite }
\end{aligned}
$$

The primary silicate minerals, such as plagioclase and clinopyroxene can be dissolved and weathered to kaolinite, $\mathrm{H}_{4} \mathrm{SiO}_{4}$ and cations such as $\mathrm{Na}^{+}$, $\mathrm{Ca}^{2+}$ and $\mathrm{Mg}^{2+}$ (Guo and Wang 2004). High concentration of $\mathrm{HCO}_{3}$ and $\mathrm{pH}$ less than 8.2 clearly indicates the intense chemical weathering processes taking place in this study region. Further, $\mathrm{Na}+\mathrm{K}$ versus total cations (figure 11c) also indicate the contribution of cations due to silicate weathering.
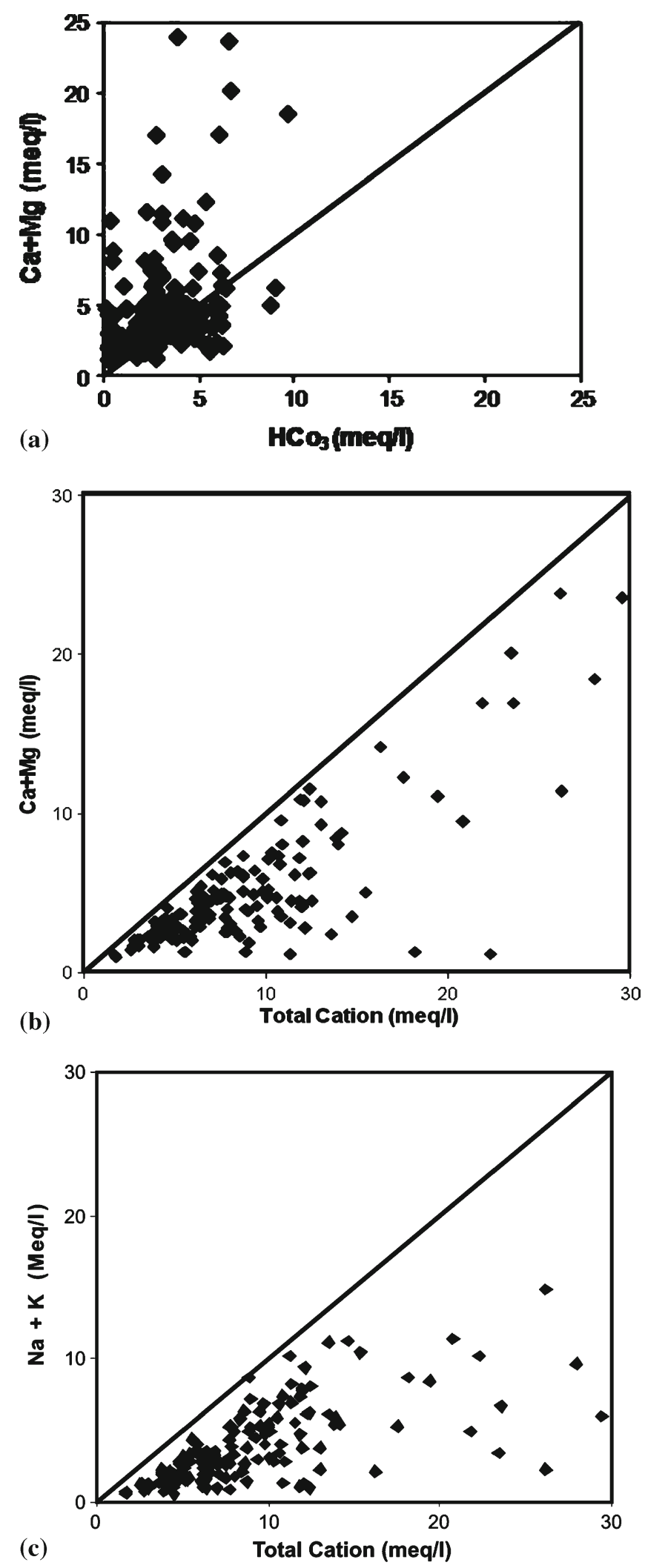

Figure 11. Relations between (a) $(\mathrm{Ca}+\mathrm{Mg})$ versus $\mathrm{HCO}_{3}$, (b) $(\mathrm{Ca}+\mathrm{Mg})$ versus total cations and $(\mathbf{c})(\mathrm{Na}+\mathrm{K})$ versus total cations indicating silicate weathering.

High ratio, estimated by the index of $(\mathrm{Na}+\mathrm{K}) /$ total cation, indicates that the cation contribution is due to silicate weathering, which is in the upper 


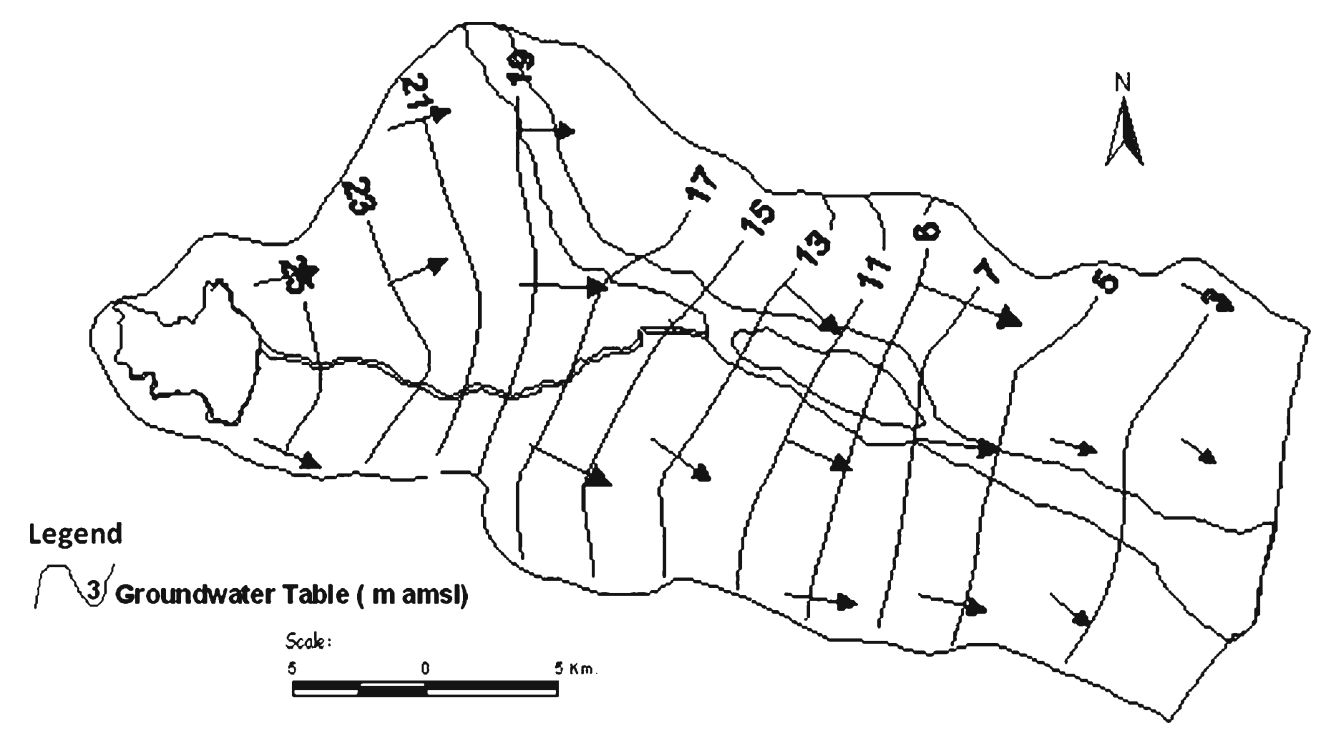

Figure 12. Spatial variation in groundwater level (m amsl) fluctuation during September 2002.

limit (Sarin et al. 1989). Thus it is evident that the major source of cations and $\mathrm{HCO}_{3}$ in the part of the lower Palar river basin is due to weathering of silicates. $\mathrm{Ca}$ and $\mathrm{Mg}$ are also contributed by weathering of silicate rich minerals such as calcicplagioclase feldspars, pyroxenes and amphiboles which are common minerals in the charnockite rocks of this area.

\subsection{Geochemical modelling}

\subsubsection{Groundwater flow from hydrochemical parameters}

Hydrogeochemical analysis of groundwater is useful not only in determining the chemistry of the groundwater, but also in understanding the movement of groundwater. Various researchers have demonstrated the relationship between the groundwater chemistry and groundwater flow. The relation between groundwater flow and its hydrochemistry is assessed and discussed. Figure 12 shows the groundwater table map indicating that in general the flow is towards the east.

The ratios $\mathrm{Ca} / \mathrm{Mg}, \mathrm{SO}_{4} / \mathrm{Cl}$ and $\mathrm{Cl} / \mathrm{HCO}_{3}$ were used to determine the groundwater flow direction in the study area. The ratio of $\mathrm{Ca} / \mathrm{Mg}$ (figure $13 \mathrm{a}$ ) decreases towards the centre of the study area which clearly shows the direction of flow of groundwater. This trend indicates the flow direction towards the southeastern direction. The ratio of $\mathrm{SO}_{4} /$ $\mathrm{Cl}$ (figure 13b) increase towards the centre from the boundary of the area. The regions of high $\mathrm{Ca} / \mathrm{Mg}$ values coincide with the regions of low $\mathrm{SO}_{4} / \mathrm{Cl}$ values, which are the regions of high topography and regions of low $\mathrm{Ca} / \mathrm{Mg}$ values coincide with regions of high $\mathrm{SO}_{4} / \mathrm{Cl}$ values, which are regions of low topography, indicating the groundwater movement.

\subsubsection{Reaction model}

NETPATH hydrochemical process code was used to analyse and assess the cation exchange and hydrogeochemical processes taking place in the aquifer system of the study area. Of the total 39 groundwater wells spread throughout the study area, the wells located in the hard rock region and in the alluvial region along the groundwater flow direction were considered for this analysis. Three flow paths, one in alluvial region, second in the transition zone of alluvium and weathered/ fractured region and other in weathered/fractured rock, were selected from the groundwater flow pattern of the part of the lower Palar river basin, evaluated from hydrochemical parameters and by numerical simulation (Senthilkumar and Elango 2001, 2004). The well nos. 11, 13 and 15 located in the weathered/fractured rock regions, and well nos. 1, 2, 3, 14 and 16 located in the alluvial regions were selected in the reaction model to assess the hydrochemical and cation exchange processes taking place in this system as they fall exactly on the groundwater flow paths.

The hydrochemical processes that were considered are:

- dissolution or precipitation of calcite,

- $\mathrm{Ca} / \mathrm{Na}$ exchange,

- $\mathrm{Mg} / \mathrm{Na}$ exchange,

- dissolution or precipitation of dolomite,

- dissolution or precipitation, and

- $\mathrm{NaCl}$ dissolution. 

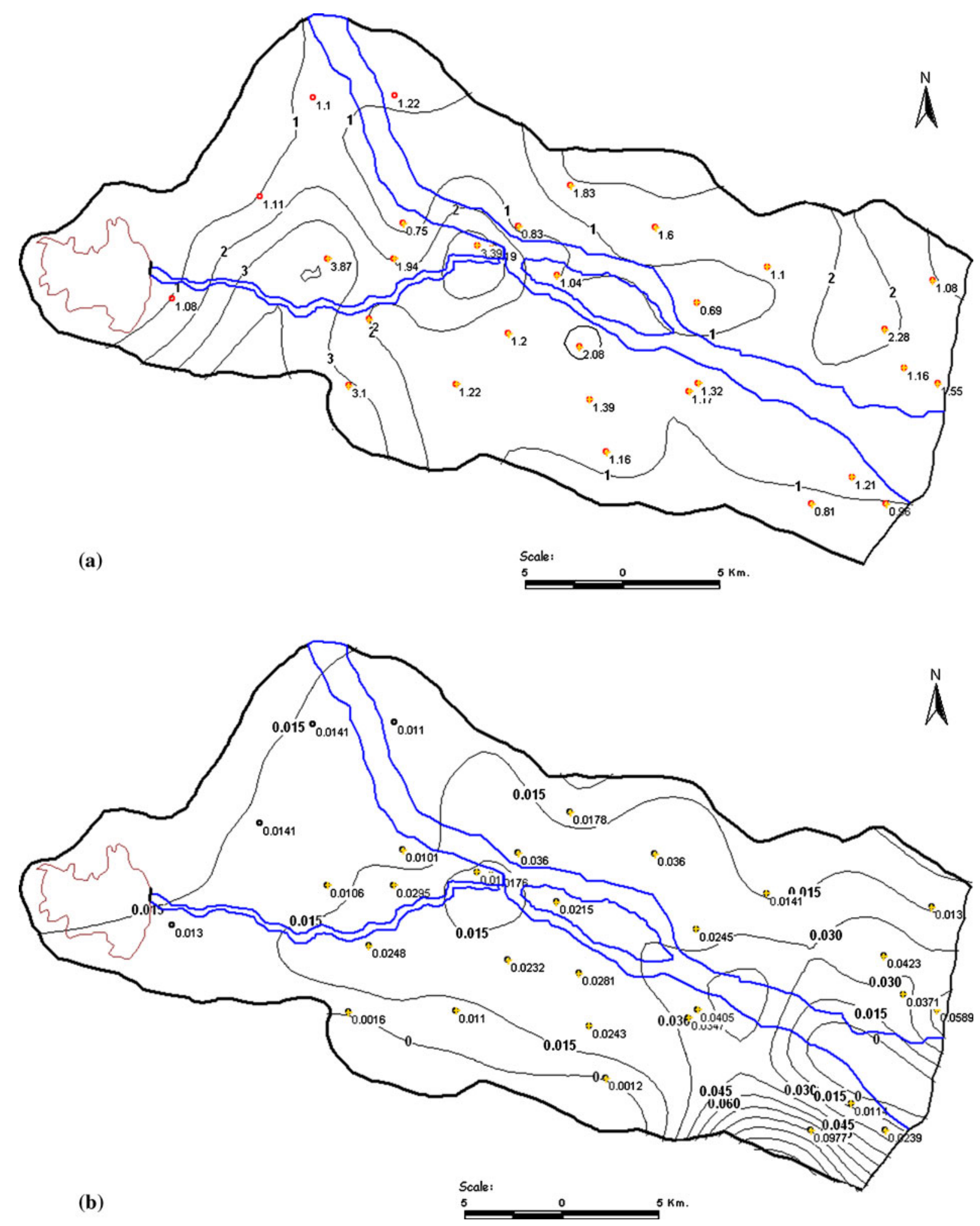

Figure 13. (a) Spatial variation in Ca:Mg ratio in groundwater during January 2002. (b) Spatial variation in $\mathrm{SO}_{4}$ : $\mathrm{Cl}$ ratio in groundwater during January 2002.

These processes were selected based on the mineralogy of the aquifer. The results of the hydrochemical reaction model are shown in table 1 . The NETPATH model results provided as many as three to five possible models based on different constraints and phases used. In each case, numerous runs were made and less realistic models were discarded, with realistic model results replicating the 
Table 1. Results of hydrochemical processes of wells located in hard rock regions.

\begin{tabular}{|c|c|c|c|c|c|c|c|c|}
\hline \multirow[b]{2}{*}{ Location } & \multirow{2}{*}{$\begin{array}{c}\text { Initial } \\
(\operatorname{Jan} 2002)\end{array}$} & \multirow{2}{*}{$\begin{array}{c}\text { Final } \\
(\text { Feb 2002) }\end{array}$} & \multicolumn{2}{|c|}{ Ionic exchanges } & \multicolumn{4}{|c|}{ Dissolution/precipitation } \\
\hline & & & $\mathrm{Ca} / \mathrm{Na}^{1}$ & $\mathrm{Mg} / \mathrm{Na}^{2}$ & Calcite* $^{*}$ & Dolomite* & K-Mont.* & $\mathrm{NaCl}^{*}$ \\
\hline \multirow{2}{*}{$\begin{array}{l}\text { Wells of weathered/ } \\
\text { fractured regions }\end{array}$} & 15 & 13 & -0.4880 & -0.2695 & -1.4357 & 0.6008 & 0.0512 & 1.7763 \\
\hline & 15 & 11 & -0.2995 & 0.1521 & 1.0582 & 0.3225 & 0.0477 & 0.5990 \\
\hline \multirow{3}{*}{$\begin{array}{l}\text { Wells of alluvial } \\
\text { regions }\end{array}$} & 16 & 14 & -0.0844 & -0.0314 & 0.4338 & 0.5094 & 0.0775 & 0.1689 \\
\hline & 1 & 2 & -0.2992 & -0.0846 & -0.5488 & -0.1180 & - & - \\
\hline & 2 & 3 & -1.1035 & -0.3858 & -0.9308 & -0.4010 & -1.2139 & - \\
\hline
\end{tabular}

1: - ve sign indicates the $\mathrm{Na}$ adsorption and release of $\mathrm{Ca}$ to water. 2: - ve sign indicates the Na adsorption and release of $\mathrm{Mg}$ to water. $*$ : - ve sign indicates precipitation; +ve sign indicates dissolution.

aquifer conditions considered. The values of mass transference show that there is no major difference in the ionic exchange between the groundwater in the hard rock and alluvial regions. Ionic exchange between $\mathrm{Ca} / \mathrm{Na}$ with exchange values ranging from -0.03 to $-2.175 \mathrm{mmol} / \mathrm{l}$ clearly indicate the release of $\mathrm{Ca}$ and adsorption of $\mathrm{Na}$ in all the regions of the study area. $\mathrm{Mg} / \mathrm{Na}$ ionic exchange results range from -0.04 to -0.75 . The negative values indicate release of $\mathrm{Mg}$ to water and adsorption of $\mathrm{Na}$ to soil. Calcite dissolution with a mass transference value ranging from 0.18 to $1.43 \mathrm{mmol} / \mathrm{l}$ is one of the important processes in wells located in the hard rock region while groundwater from wells located in the alluvial region show calcite precipitation as the important process. In case of the reactions between the wells 15 and 13 located in the hard rock regions, the $\mathrm{Ca} / \mathrm{Na}$ exchange indicates the release of $\mathrm{Ca}$ and adsorption of $\mathrm{Na}$, precipitation of calcite, dolomite dissolution, K-montmorillonite dissolution and $\mathrm{NaCl}$ dissolution. Among the cation exchange processes taking place in the study area, release of $\mathrm{Ca}$ and $\mathrm{Mg}$ and adsorption of $\mathrm{Na}$ is more evident in the wells located in the hard rock regions and in the alluvial regions.

\section{Conclusion}

Groundwater in the study area covering a part of the lower Palar river basin, southern India is dominated by $\mathrm{Na}, \mathrm{Ca}$ and $\mathrm{HCO}_{3}$ ions. Groundwater in the weathered rocks of the area has relatively high $\mathrm{Na}$ concentration while groundwater occurring in the alluvial formations has high Ca content. The cation exchange process and silicate weathering control the groundwater chemistry in this area. Hydrochemical reaction modelling indicates the release of $\mathrm{Ca}$ and adsorption of $\mathrm{Mg}$ and $\mathrm{Na}$ by ion exchange processes along the groundwater flow path. Other important processes include the dissolution and precipitation of minerals. Groundwater of this area is suitable for domestic purposes except for a few locations where high $\mathrm{EC}, \mathrm{pH}$ and other dissolved ions make it unsafe for drinking.
High SAR, RSC and Na\% in few locations restricts its suitability for agricultural activities.

\section{References}

Aghazadeh N and Mogaddam A A 2011 Investigation of hydrochemical characteristics of groundwater in the Harzandat aquifer, Northwest of Iran; Environ. Monit. Asses. 176(1-4) 183-195.

Al-Sabahi E, Rahim S A, Zuhairi W Y W, Al-Nozaily F and Alshaebi F 2009 The characteristics of leachate and groundwater pollution at municipal solid waste landfill of Ibb City, Yemen; Am. J. Environ. Sci. 5(3) 256266.

Andrade A I A S S and Stigter T Y 2011 Hydrogeochemical controls on shallow alluvial groundwater under agricultural land: Case study in central Portugal; Environ. Earth Sci. 63(4) 809-825.

APHA 1995 Standard Methods for the Examination of Water and Wastewater; 19th edn, APHA Washington DC.

Arumugam K and Elangovan K 2009 Hydrochemical characteristics and groundwater quality assessment in Tirupur Region, Coimbatore District, Tamil Nadu, India; Environ. Geol. 58(7) 1509-1520.

Bakis R and Tuncan A 2011 An investigation of heavy metal and migration through groundwater from the landfill area of Eskisehir in Turkey; Environ. Monit. Assess 176(1-4) 87-98.

Belkhiri L, Boudoukha A and Mouni L 2010 Groundwater quality and its suitability for drinking and agricultural use in Ain Azel plain, Algeria; J. Geogr. Reg. Plan. 3(6) 151-157.

Brindha K, Elango L and Rajesh V G 2010 Occurrence of chromium and copper in groundwater around tanneries in Chromepet area of Tamil Nadu, India; Indian J. Environ. Protection 30(10) 818-822.

Brindha K and Elango L 2012 Impact of tanning industries on groundwater quality near a metropolitan city in India; Water Resour. Manag. 26(6) 1747-1761.

Dar I A, Sankar K, Shafi T and Dar M A 2011 Investigation of groundwater quality in hardrock terrain using Geoinformation System; Environ. Monit. Assess. 176(1-4) $575-595$.

Eaton F M 1950 Significance of $\mathrm{CO}_{3}$ s in irrigation waters; Soil Sci. 39 123-133.

Elango L 1992 Hydrogeochemistry and mass balance modelling of multilayered aquifers; Unpublished PhD thesis, Anna University, Chennai, India, 181p.

Elango L, Kannan R and Senthilkumar M 2003 Major ion chemistry and identification of processes of groundwater in the part of the Kancheepuram district, Tamilnadu, India; Environ. Geosci. 10(4) 157-166. 
Fisher R S and Mullican III W F 1997 Hydrochemical evolution of $\mathrm{Na}-\mathrm{SO}_{4}$ and $\mathrm{Na}-\mathrm{Cl}$ groundwater beneath the northern Chihuahuan desert, Trans-Pecos, Texas, USA; Hydrogeol. J. 5(2) 4-16.

Gibbs R J 1970 Mechanisms controlling worlds water chemistry; Science 170 1088-1090.

Gowd S S 2005 Assessment of groundwater quality for drinking and irrigation purposes: A case study of Peddavanka watershed, Anantapur District, Andhra Pradesh, India; Environ. Geol. 48 702-712.

Guo H and Wang Y 2004 Hydrogeochemical processes in shallow quaternary aquifers from the northern part of the Datong Basin, China; Appl. Geochem. 19(1) 19-27.

ISI (Indian Standards Institution) 1983 Indian Standard specification for drinking water, IS 10500.

Jalali M 2010 Groundwater geochemistry in the Alisadr, Hamadan, western Iran; Environ. Monit. Assess. 166(1-4) 359-369.

Jankowski J and Acworth R I 1997 Impact of debris-flow deposits on hydrogeochemical processes and the development of dryland salinity in the Yass River catchment, New South Wales, Australia; Hydrogeol. J. 5(4) 71-88.

Kumaresan M and Riyazuddin P 2006 Major ion chemistry of environmental samples around sub-urban of Chennai city; Curr. Sci. 91(12) 1668-1677.

Laluraj C M and Gopinath G 2006 Assessment on seasonal variation of groundwater quality of phreatic aquifers - A river basin system; Environ. Monit. Assess. 117 45-57.

Li X D, Masuda H, Kusakabe M, Yanagisawa F and Zeng H A 2006 Degradation of groundwater quality due to anthropogenic sulfur and nitrogen contamination in the Sichuan Basin, China; Geochem. J. 40 309-332.

Mazari M and MacKay D M 1993 Potential for groundwater contamination in Mexico City; Environ. Sci. Technol. 27(5) 794-802.

Meybeck M 1987 Global chemical weathering of surficial rocks estimated from river dissolved loads; Am. J. Sci. 287 401-428.

Mohan R, Singh A K, Tripathi J K and Chowdhary G C 2000 Hydrochemistry and quality assessment of groundwater in Naini industrial area, Allahabad district, Uttar Pradesh; J. Geol. Soc. India 55 77-89.

Özcan H, Ekinci H, Baba A, Kavdır Y, Yüksel O and Yi gini Y 2007 Assessment of the water quality of Troia for the multipurpose usages; Environ. Monit. Assess. 130 389-402.

Plummer L N, Prestemon E C and Parkhurst D L 1991 An interactive code (NETPATH) for modeling net geochemical reactions along a flow path: US Geological Survey Water Resources Investigations Report 91-4087, 227p.

PWD (Public Works Department) 2000 Groundwater perspectives: A profile of Kancheepuram district, Tamil Nadu: Tamil Nadu Public Works Department.

Rajmohan N and Elango L 2004 Identification and evolution of hydrogeochemical processes in an area of the Palar and Cheyyar River Basin, Southern India; Environ. Geol. 46 47-61.

Raju N R 2006 Seasonal evaluation of hydro-geochemical parameters using correlation and regression analysis; Curr. Sci. 91(6) 820-826.

Raju N J, Ram P and Dey S 2009 Groundwater quality in the Lower Varuna River Basin, Varanasi District, Uttar Pradesh; J. Geol. Soc. India 73 178-192.
Raju N J, Shukla U K and Ram P 2011 Hydrogeochemistry for the assessment of groundwater quality in Varanasi: A fast-urbanizing center in Uttar Pradesh, India; Environ. Monit. Assess. 173 279-300.

Rao N S 2006 Seasonal variation of groundwater quality in a part of Guntur District, Andhra Pradesh, India; Environ. Geol. 49 413-429.

Rao N S 2008 Factors controlling the salinity in groundwater in parts of Guntur district, Andhra Pradesh, India; Environ. Monit. Assess. 138(1-3) 327-341.

Reddy A G S and Kumar K N 2010 Identification of the hydrogeochemical processes in groundwater using major ion chemistry: A case study of Penna-Chitravathi river basins in southern India; Environ. Monit. Assess. 170 365-382.

Reddy A G S, Reddy D V, Rao P N and Prasad K M 2010 Hydrogeochemical characterization of fluoride rich groundwater of Wailapalli watershed, Nalgonda district, Andhra Pradesh, India; Environ. Monit. Assess. 171 $561-577$.

Rosen M and Jones S 1998 Controls on the chemical composition of groundwater from alluvial aquifers in the Wanaka and Wakatipu basins, central Otago, New Zealand; Hydrogeol. J. 6 264-281.

Rouxel M, Molénat J, Ruiz L, Legout C, Faucheux M and Gascuel-Odoux C 2011 Seasonal and spatial variation in groundwater quality along the hillslope of an agricultural research catchment (Western France); Hydrol. Process. 25(6) 831-841.

Salama R B 1993 The chemical evolution of groundwater in a first-order catchment and the process of salt accumulation in the soil profile; J. Hydrol. 143 233-258.

Sarin M M, Krishnaswamy S, Dilli K, Somayajulu B L K and Moore W S 1989 Major ion chemistry of the GangaBrahmaputra river system: Weathering processes and fluxes to the Bay of Bengal; Geochim. Cosmochim. Acta 53 997-1009.

Satyanarayanan M, Balaram V, Hussin M S A, Jemaili M A R A, Rao T G, Mathur R, Dasaram B and Ramesh S L 2007 Assessment of groundwater quality in a structurally deformed granitic terrain in Hyderabad, India; Environ. Monit. Assess. 131 117-127.

Senthilkumar M and Elango L 2001 Numerical simulation of groundwater flow regime in a Part of the Lower Palar River Basin, southern India; In: Modelling in Hydrogeology (eds) Elango L and Jayakumar R, Allied Publ. $270 \mathrm{p}$.

Senthilkumar M and Elango L 2004 Three-dimensional mathematical model to simulate groundwater flow in the lower Palar River basin, southern India; Hydrogeol. J. 12(4) 197-208.

Tirumalesh K, Shivanna K, Sriraman A K and Tyagi A K 2010 Assessment of quality and geochemical processes occurring in groundwaters near central air conditioning plant site in Trombay, Maharashtra, India; Environ. Monit. Assess. 163(1-4) 171-184.

Vijay R, Khobragade P and Mohapatra P K 2011 Assessment of groundwater quality in Puri City, India: An impact of anthropogenic activities; Environ. Monit. Assess. 177(1-4) 409-418.

WHO (World Health Organisation) 1984 Guidelines for drinking water quality; VI, Recommendation, World Health Organisation, Geneva, 130p. 